\title{
Research on the origin of clothing from the perspective of the ancient Chinese character etymology and philosophy
}

DOI: $10.35530 / I T .072 .06 .1763$

QIANG LI

YIXIAO LI

ANDING LIU

XIANMING XU

BIN LI

HUI TAO

\section{ABSTRACT - REZUMAT \\ Research on the origin of clothing from the perspective of the ancient Chinese character etymology and philosophy}

The origin of clothing has always been one of the most important topics in the field of apparel culture research. However, academics have different opinions on this issue. Based on the dilemma analysis of the three research routes which include philology, archaeology, anthropology, we can study the essence of the origin of clothing by analysing ancient Chinese character and philosophy. The relative methods of characters etymology in ancient China, archaeology, anthropology and philosophy are adopted in this study in order to further study the origin of clothing. The research shows that: from etymology research on characters in ancient China, Chinese characters associated with clothing can reflect the objective needs of clothing-the carrying tools whose material are cortex. From the perspective of philosophical researches, clothing prototype originated in the cortical belt for carrying in the process of human evolution during the Palaeolithic. It is an important tool for primitive humans to increase their survival rate. And formed clothing is necessary for them to get out of the Africa and expand their living space. First of all, this paper systematically demonstrates the idea that clothing originated from tools based on the analysis of ancient Chinese characters. Secondly, from the perspective of philosophy, this paper demonstrates the great historical role of clothing as a survival tool, based on the viewpoint that the generation of clothing precedes the consciousness of clothing.

Keywords: clothing, evolution, tools, origin, Oracle

Cercetări privind originea îmbrăcămintei din perspectiva etimologiei și filosofiei antice chineze

Originea îmbrăcămintei a reprezentat întotdeauna unul dintre cele mai importante subiecte în domeniul cercetării culturii îmbrăcămintei. Cu toate acestea, cadrele universitare au opinii diferite cu privire la această problemă. Pe baza analizei dilemei celor trei rute de cercetare care includ filologia, arheologia și antropologia, putem studia esența originii îmbrăcămintei prin analiza caracterului și filosofiei antice chineze. Metodele relative ale etimologiei caracterelor din China antică, arheologia, antropologia și filozofia sunt adoptate în acest studiu pentru a studia originea îmbrăcămintei. Cercetarea arată că: din cercetările etimologice asupra caracterelor din China antică, caracterele chinezești asociate cu îmbrăcămintea pot reflecta nevoile obiective ale îmbrăcămintei - instrumentele de transport al căror material este cortexul. Din perspectiva cercetărilor filozofice, prototipul vestimentar își are originea în centura corticală pentru purtare în procesul de evoluție umană din timpul paleoliticului. Este un instrument important pentru oamenii primitivi pentru a-și crește rata de supraviețuire, iar îmbrăcămintea este necesară pentru ca ei să părăsească Africa și să-și extindă spațiul de locuit. În primul rând, această lucrare demonstrează sistematic ideea că îmbrăcămintea provine din instrumente bazate pe analiza caracterelor antice chineze. În al doilea rând, din perspectiva filozofiei, această lucrare demonstrează marele rol istoric al îmbrăcămintei ca instrument de supraviețuire, pornind de la punctul de vedere că generarea îmbrăcămintei precede conștiința îmbrăcămintei.

Cuvinte-cheie: îmbrăcăminte, evoluție, unelte, origine, Oracol

\section{INTRODUCTION}

There are more than ten academic viewpoints on the origin of clothing. The representative ones are Body Protection Theory, Theory of Warm-keeping, Sexual Attraction Theory, Shame Theory, Decorative Theory, etc. However, there are historical explanations on the basis of the version of Whig in the researches. In fact, clothing research is just a sub-path in many human evolutionary routes, which is a tool and means of human evolution to a more civilized stage. In recent years, Bernard's view [1] that "clothing originated from carrying tools" has begun to attract the attention of the many researchers. Since Bernard simply proposed this point, Tao Yuan et al. [2] demonstrated the origin of clothing as a tool by analysing the source of ancient Chinese characters and using the speculative deduction method combined with facts.

Ancient Chinese characters refer to the Chinese characters used from Shang to Qin dynasties, mainly including Oracle, bone inscriptions and seal characters. Chinese characters, as pictographic and ideographic characters, basically preserved the pictographic features [3]. From the very beginning, pictographic 
characters have already contained symbolic meanings that transcend analogue objects. It is this aspect that makes pictographs of Chinese characters different from paintings in essence, being of unique abstract meanings value and function of symbols [4]. Therefore, pictographs of ancient Chinese characters can reflect the fundamental intention of the characterbuilding, and can also restore the original of the things described at the beginning of the character creation. Based on the analysis of the dilemma of the conventional route of clothing origin, this paper initiated and conducted in-depth research on the viewpoint that clothing originated from leather belt.

\section{THE DILEMMA OF THE CONVENTIONAL RESEARCH ROUTE OF CLOTHING ORIGIN}

The conventional research route of clothing origin mainly includes three research aspects: philology, archaeology and anthropology. However, because clothing originated from the beginning of human evolution, it belongs to the category of prehistoric civilization, which is far away from the modern time, resulting in contradictory views on documents and serious lack of cultural relics in archaeological research. Anthropology, on the other hand, studies the language, behaviour and social attributes of modern "primitive man" and then makes a reverse extrapolation of the living state of the real primitive man. Therefore, these three research aspects all have their own research dilemmas.

\section{The dilemma of conflicting viewpoints in philology}

Philology refers to the study of reading, collecting, organizing, researching and utilizing ancient literature. China still maintains vast ancient literature, including a large number of records of human life in ancient times. Summarizing the literature related to the origin of clothing, it is found that these ancient documents mainly include the viewpoint of the protection of clothing origin. There are quite a few ancient Chinese Confucian and Taoist documents that hold the view of clothing origin protection. The Chinese Dictionary Shi Ming written by Liu Xi, a scholar of Han Dynasty, pointed out: "The main function of garments is the tools that people use to keep warm and prevent heat". Chuang Tzu stated that "Human beings had no clothes at the beginning. They collected combustible materials in summer and burned them to keep warm in winter. In the time of Yan Emperor, it was still in the matriarchal society, and people had begun farming and weaving clothes" [5]. However, Confucianism and Taoism have different concepts about clothing: Shi Ming believes that clothing is used to avoid the heat and cold, but does not clearly point out that the material of the clothing must be textile fabrics; and Chuang Tzu's Chuang Tzu clearly points out those only woven clothes.

In addition, with regard to the time of the origin of clothing, the views of Confucianism and Taoism are quite different. According to The book of Rites regarded as a classic by Confucian, "At first, humans could not build houses, lived in caves in winter, in summer they built nests on trees like birds. They did not know how to use fire, and they ate the fruits of plants and meat of animals. They lived a very primitive life. At the same time, there was no textile technology, only the feathers and furs of birds and animals could be used as clothes" [6]. Therefore, Confucian scholars believed that clothing had appeared before the ancestors used fire, however humans have been using fire for 500,000 years or more [7].On the contrary, according to Chuang Tsu, clothing originated from the era of the Yan Emperor, after the ancestors used the fire, which was about 5,000 years ago. Since origin of clothing happened in the ancient times, there are contradictory views on the origin of clothing from the perspective of philology.

In fact, there are still some problems in using the ancient literature to study the origin of clothing. Firstly, the date of the appearance of these ancient documents needs to be verified to determine the minimum age of their views. For example, the records on the origin of clothing in The Book of Rites can only reflect a view on the origin of clothing in the time when The Book of Rites was written because the ancients looked at the origin of clothing with the "Whig" view of history. Secondly, the authenticity and edition of ancient documents need to be ascertained. On the one hand, although there are many ancient Chinese documents, they are also mixed with some fake books, which were written by ancient people in the guise of ancient celebrities [8]. On the other hand, the issue of the version of Chinese ancient literature is also a big problem. Ancient Chinese documents have been circulating for a long time. Different versions have been produced due to the problems of copying, printing, recompiling, adding and deleting. Therefore, the earliest version of the records concerning the origin of clothing needs to be determined so as to obtain accurate information.

\section{The dilemma of the serious lack of cultural relics in archaeological research}

Because the fabric is extremely perishable, it is obviously unrealistic to find the earliest Chinese clothing. However, the bone needles for making garments can be turned into fossils and preserved for a long time. Therefore, the discovery of bone needles is of great significance for studying the lower limit of the origin of clothing. According to the current archaeological findings in China, bone needles have appeared in the late Palaeolithic age in China, indicating that the origin of Chinese clothing should be no later than the late Palaeolithic age. For example, in 1930, the earliest bone needle in China was found in the ruins of the Upper Cave Man at Longgu Mountain in Zhoukoudian, Fangshan District, and suburb of Beijing (figure 1). The bone needle is $8.2 \mathrm{~cm}$ long, only the thickness of the match stick, the needle body is slightly curved, and the scraping is smooth. One end of the bone 
needle is a sharp tip, and the other end is a needle eye made of extremely sharp objects. Although the needle eye was damaged when it was found, it is not difficult to see its original appearance. The discovery of bone needles proved that the Upper Cave Man had the ability to sew clothes and was no longer naked [9]. According to the C14 test of the animal bones unearthed at the same time, the age of the Upper Cave Man should be about 11,000 years ago [10]. That is to say, the origin of Chinese clothing should be far earlier than 11,000 years ago.

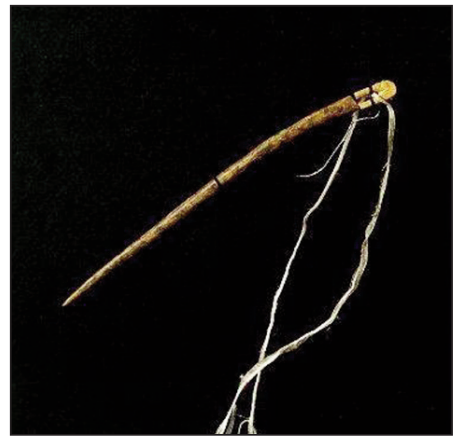

Fig. 1. The bone needle of Upper Cave Man

In addition, bone needles are not seen in the site of primitive men in China, which is older than Upper Cave Man, but that doesn't show the primitive people didn't have clothing. Archaeological methods can hereby only determine the lower limit of the time of clothing origin, but cannot research further, because the original clothing was probably the animal skin on the body and did not need to be stitched with a needle.

\section{The dilemma of over-generalization in} anthropological research

Anthropology and ethnography have accumulated a large amount of materials for the clothing of modern "primitive society". From these materials, it seems that most of them can provide some reasonable evidence for the theory of aesthetic origin and identifi- cation of clothing. Anthropology research route is usually aimed at the clothing behaviour of "primitive people" in some existing primitive tribes. However, there are some inborn defects in this research route. First of all, what anthropology studies are not the primitive people of prehistoric times? It is the modern "primitive man". These "primitive people" may retain the thinking characteristics of some primitive people in prehistoric times. But there is environment difference between the two. Therefore, motives in use of the modern "primitive" clothing and the prehistoric primitives' clothing cannot match. Secondly, the development of modern "primitive people" is far from reaching the state of civilization, and their living environment is relatively closed and single, which can only be considered as one of the choices in the process of human civilization. Naked modern "primitive man" may be unable to start the civilization process because of lack of stimulation of clothing motivation.

\section{THE ANALYSIS ON ETYMOLOGY OF ANCIENT CHINESE CHARACTER}

\section{The original clothing is the carrying tool}

From the analysis on the source of Chinese ancient characters, there is a close relationship between the origin of clothing and tools. In accordance with the viewpoints and argumentation methods of Tao Yuan and Yu Weidong that clothing are used as containers for carrying goods, some ancient Chinese characters (table 1) related to clothes are classified in detail. As shown in table 1, in oracle bone inscriptions, the word "Yi (clothing)" in Chinese characters is very similar to the object composed of two curved sheets. In the meantime, when it is used as etymon, all have the meaning of wrappage.

\section{The original clothing was made of leather}

The ancient Chinese character "Yi (clothing)" can not only suggest that clothes originated from tools, but also reflect materials of the most primitive clothing. It can be seen from table 2 that some ancient Chinese characters related to the original clothing materials,

Table 1

\begin{tabular}{|c|c|c|c|}
\hline \multicolumn{4}{|c|}{$\begin{array}{l}\text { AUXILIARY CLOTHING ORIGINATED IN THE TOOL PART OF THE ANCIENT CHINESE WORD } \\
\text { SOURCE ANALYSIS TABLE }\end{array}$} \\
\hline $\begin{array}{c}\text { Modern Chinese } \\
\text { characters }\end{array}$ & Word origin & Glyph decomposition & $\begin{array}{l}\text { The original meaning } \\
\text { of Chinese characters }\end{array}$ \\
\hline 衣 & $\begin{array}{c}\hat{\imath} \\
\text { (Oracle) }\end{array}$ & $\wedge$ and $\uparrow$ & $\begin{array}{l}\text { The container for holding things composed } \\
\text { of two curved sheets }\end{array}$ \\
\hline 裹 & $\begin{array}{c}\text { 稥 } \\
\text { (Seal character) }\end{array}$ & $\hat{\mathrm{N}}$ (clothing) and 思 (fruit) & $\begin{array}{l}\text { The ancients used clothes to pack wild } \\
\text { fruits from the mountains }\end{array}$ \\
\hline 装 & $\begin{array}{c}\text { 斏 } \\
\text { (Seal character) }\end{array}$ & 肚 (man) and $\hat{\aleph}$ (clothing) & Ancient man picked for the long journey \\
\hline 奋 & $\begin{array}{c}\text { (10 } \\
\text { (Bronze inscriptions) }\end{array}$ & $\begin{array}{l}\widehat{v} \text { (clothing) and } \underset{\&}{\text { (bird })} \\
\quad \text { and } \boxplus \text { (field) }\end{array}$ & Using clothing to capture birds in the field \\
\hline
\end{tabular}




\begin{tabular}{|c|c|c|c|}
\hline \multicolumn{4}{|c|}{$\begin{array}{c}\text { ANALYSIS TABLE ON SOURCE OF THE ANCIENT CHINESE CHARACTER REFLECTING } \\
\text { THE ORIGINAL CLOTHING MATERIALS }\end{array}$} \\
\hline $\begin{array}{l}\text { Modern Chinese } \\
\text { characters }\end{array}$ & Word origin & Glyph decomposition & $\begin{array}{l}\text { The original meaning } \\
\text { of Chinese characters }\end{array}$ \\
\hline 装 (Qiu) & $\begin{array}{c}\text { 狇 } \\
\text { (Oracle) }\end{array}$ & 仓 (clothing) and "; (fur) & Fur coat \\
\hline 衰 (Shuai) & $\begin{array}{c}\text { 赛 } \\
\text { (Seal character) }\end{array}$ & $\begin{array}{c}\hat{\widehat{N}} \text { (clothing) and } \\
\text { fa large number of palm } \\
\text { fibre that are drooping down) }\end{array}$ & $\begin{array}{l}\text { The ancients connected the palm leaves of } \\
\text { the fibre down to "palm-woven rain-cloak" }\end{array}$ \\
\hline 褐 $(\mathrm{He})$ & $\begin{array}{c}\text { 罩 } \\
\text { (Seal character) }\end{array}$ & 令 (clothing) and 曷 (vine) & $\begin{array}{l}\text { Ragged clothes made from kudzu and } \\
\text { hemp }\end{array}$ \\
\hline
\end{tabular}

and fabrics of the most original clothing must be made of leather. As can be reflected by The Oracle "Qiu (fur coat)" and the seal character "He (coarse clothing)". On the one hand, from the glyph of the word "Qiu" in Oracle, it is like a coat covered with fur. Then, the clothing must be leather at first. Seal character "Shuai (the weeds made of burlap in ancient times)" is clothing made of brown fur. On the other hand, the seal character "He (coarse clothes)" reflects the "clothing" made from rattan plant fabrics such as kudzu and hemp. If the initial material of clothing is plant fibre like kudzu and hemp, then the pictograph of "He (coarse clothes)" should be the initial shape of ancient Chinese character "Yi (clothing)", however that was not the case. Therefore, there is no doubt that at least the material of the original clothing in China should be made of leather.

\section{The original clothing is made of leather belt}

The shape and structure of the original clothing has always been a controversial topic in the field of clothing history. In fact, Oracle can also provide us with key clues. The shape of the original clothing should be a leather belt, as was evidenced by the oracle "Jin (Small piece of textile)" and "Dai (belt)" (table 3). First of all, from the oracle's pictograph of "Jin", it is very similar to the fig leaf that blocks the front crotch. The accessories of ancient Chinese clothing "Bixi" (a kind of clothing used by both men and women in the ancient Central Plains, covering the thighs to the knees) should be its remains, but the width of "Bixi" becomes very narrow and only exists for decoration. Secondly, judging from the pictograph of the oracle bone inscriptions "Dai", the word "Dai (belt)" is a long, flat strap worn around the waist to fasten a skirt.

\section{PHILOSOPHICAL ANALYSIS}

\section{The essence of clothing}

There are three dimensions to understand the essence of clothing. One is to regard clothing as the need of human survival and development, which came into being when human society developed to a certain social stage. Thus, it can be revealed that the origin of clothing is the result of existence determining consciousness. Second, clothing is seen as the requirement of human aesthetic art, which appeared as an aesthetic object when it entered the society, it was concluded that the origin of clothing was the result of aesthetic consciousness. Third, clothing is regarded as the psychological needs of human beings, whose origin is to meet the psychological needs of individual differences of human beings, which ultimately leads to the conclusion that consciousness determines the existence.

According to Abraham Harold Maslow's hierarchy of needs (AD 1908-1970), human needs are physiological needs, safety needs, social needs, respect needs and self-actualization needs from low to high.

\begin{tabular}{|c|c|c|c|}
\hline \multicolumn{2}{|c|}{ ANALYSIS TABLE OF SOME ANCIENT CHINESE CHARACTER SOURCE RELATED TO THE SHAPE } \\
AND STRUCTURE OF THE ORIGINAL CLOTHING
\end{tabular}


There is no doubt that primitive humans lived a precarious life, and the satisfaction of their physical needs must be their first priority. The leather belt and the rudiment of clothing both played a crucial role as an effective tool to improve the efficiency of food acquisition. In fact, from the order of the ancient Chinese people's "clothing, food, housing and transportation", it can be seen that "clothing" is of the key status in the minds of Chinese ancients, because "clothing" was once the most important survival tool for the hominids. First of all, "clothing" is a tool for survival and development, being very logical for "clothing" to be ranked before "food". Without the existence of such an important tool as "clothing", there would be no reliable guarantee for the acquisition of "food". Secondly, when people solve the problem of "food", then solve the problem of security - "housing" is hereby taken for granted. Finally, when the security problem is solved, human's means of expanding and developing the space - "transportation" is highlighted. Apparently, the explanation of the sequence of "food, clothing, housing and transportation" fully conforms to Maslow's hierarchy of needs and Marx's theory that "production material is life itself". Therefore, based on the order of "clothing, food, housing and transportation", clothing must be an important survival tool in the process of human evolution.

\section{The conditions under which primitive man had clothing}

When discussing the conditions under which primitive man had clothing, it is generally acknowledged that the conditions were depended on clothing material, manufacturing processes and motivation. First of all, from the perspective of the clothing materials, the academic community generally believes that leather clothing is used in the cold northern regions, while "huifu" is used in the warm southern regions. However, from the perspective of the etymology of ancient Chinese characters, as the main body of farming civilization, Han nationality's original clothing material was leather. With the invention of plant fibre technology, the main body of its clothing material was transformed from leather into plant fibre products. At the same time, the use of the leaves as a cover or decoration of the body is not a real clothing. On the one hand, if the leaves are not preserved for a long time without a certain process, they cannot be used as an appendage of the body; on the other hand, the body cover made by the vine leaves cannot show the identity and status of the individual compared with the fur. In East Africa, for example, the chief wears an armband and a foot ring made of a giraffe's tail to distinguish him from other members [11]. It can be seen that as the eastern part of the tropics, the temperature is hot, but the animal's fur logo is used instead of the vine leaves when the leader status is displayed. Secondly, from the point of view of the manufacturing process of clothing, the bone needle can be used as a key tool. Bone needles, however, can only be used for fur or fabric instead of foliage. The use of fur in clothing is much earlier than the use of plant fibre abrics, the origin of the clothing technology is obvious for the use of fur. Finally, from the relationship between dressing facts and dressing motives, the production of clothing objects is much earlier than the dressing motive. Therefore, the dressing motive cannot be used to reasonably explain the origin of clothing; the explanation is also a Whig explanation.

\section{The purpose of primitive dressing}

The purpose of primitive dressing is not its motivation but its value. According to Darwin's Theory of Evolution, humans have evolved from ape-man, being covered with hair. Meanwhile, the application of modern molecular biology in anthropology continues to strengthen the argument that modern humans originated from Africa and spread to other regions. Through the analysis of genetic variation in high-flux populations, we can further infer the time of early modern people going out of Africa and reaching nodes around the world [12]. It was only about 1.8 million to 2 million years ago that humanity left Africa and spread rapidly in Eurasia [13]. Africa is located in tropical and subtropical areas, which account for more than $95 \%$ of the total area. Even in the Quaternary (3 million years ago) when humans were born, there was no cold climate. Therefore, hominids did not have the need to protect themselves from the cold. The value of clothing can only be seen in the process of human evolution. Engels once pointed out that labour created the people themselves, but labour also created human clothing. The primitive leather belt of the clothing has played an active role in the evolution of human beings, and the formed clothing is necessary means for humans to expand their living space.

\section{The important role of the original leather belt from the perspective of human evolution}

The leather belt has always been playing a positive role in human evolution. No matter what kind of civilization or culture, whether it is a highly developed ancient civilization or a "modern primitive man" in a naked state, there are many differences in clothing, possessing a belt is their common feature. Therefore, it is reasonable to look at the role that the leather belt has played, and to stand in the perspective of human evolution and make reasonable inferences.

First, hair removal is the first step in human evolution. Humans belong to omnivorous primates, and meat plays a key role in the evolution of human beings. In order to effectively capture the prey, continuous running has become the initial magic weapon for human beings. In the meantime, continuous running requires a fundamental change in the heat dissipation mechanism of humans. Humans gradually got accustomed to using the skin for effective heat dissipation, becoming the only animal in all terrestrial mammalian to use the whole body skin for heat dissipation. Thus, human beings appear on the African savanna in a naked image.

Secondly, tool manufacturing is a sign that humans are different from other animals. However, the tools 
used need carrying. The tools for hunting includes not only stone spears, slings, etc., but also stone knives, wooden knives, and bone knives used to cut animal carcass. Therefore, effective methods are needed to carry tools for cutting animal carcasses. There are two ways to carry the tools. One is to tie the tools to the body in series by means of a linear soft substance. The other is to use sheet-like soft material to directly wrap and tie it around the waist [2]. Both of the ways of carrying tools can be found in traditional Chinese clothing. For instance, Die Xie belt (figure 2) is the one that combines two ways of carrying. Die Xie belt was originally an important accessory in the clothing of the Western Regions nomads with tools such as knives, syringes and whetstone. From the perspective of historical development, Die Xie belt removes the decoration and retains only the function, so its original leather belt and wrappage is an effective carrying tool, which should be the origins of clothing. It's in the course of human evolution that the core objects eventually become accessories for clothing.

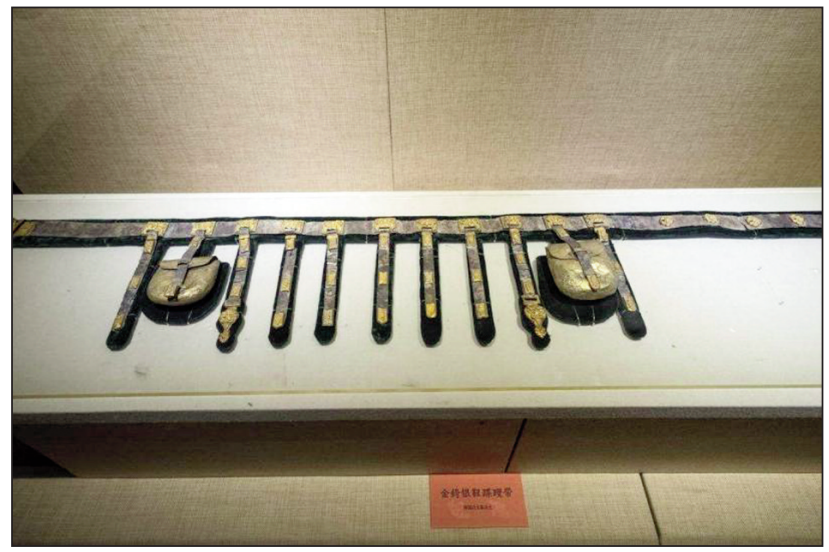

Fig. 2. Golden Die Xie belt used for carrying tools

Finally, the emergence of the leather belt contributed to human evolution. The production of leather belt is the origin of human clothing; it is also a labour tool at the beginning. Ernst Grosse, a famous German art historian, pointed out that the original belt was usually not decorated, probably because the practical significance was large and the decorative purpose was small. The first function of the belt was to carry small weapons and tools, the second function being a waistband to alleviate hunger [14]. From this we can see that the prototype waistband of clothing is a form of people's own production of material life, being the creation of human intelligence in the motivation to improve the survival rate, a powerful means to get rid of the animal state, as well as a material confirmation of human freedom.

\section{Shaped clothing is a necessary means for humans to expand their living space}

Clothing is not only an important tool to improve the survival rate of human beings, but also a necessary means to expand the survival space of human beings. The gradual degeneration of primitive men's hair fully demonstrates the importance of survival strategy change in the evolutionary process. However, the degradation of hair causes primitive humans to appear on the African savanna in a state of nature. With the growth of population and the shrinking of living space, some primitive humans left African continent in batches and spread to other continents in order to better survive. However, other continents are not as warm as the ancient African grasslands, and the degradation of hair requires human beings to improve their ability to withstand cold, especially the cold climate during the fourth ice age, which made primitive human beings face an unprecedented crisis. Humans can only solve this crisis effectively by developing a split clothing based on the belt, settling in caves, relying on fire to warm up, and covering the body with animal skins [15]. As a universal means of survival in other continents (Individual low-level primitive cultures may not have developed into this stage, but the degree of population and cultural development can be explained by the fact that there is no invention of clothing, and it is impossible to change from culture to civilization.). Without the invention of clothing, human beings would not be able to expand to all the continents of the world except Antarctica in a civilized manner. Therefore, the real formation of clothing is a necessary means for human beings to expand their living space. Therefore, the shape and structure of the original clothing is worth pondering. As an important tool of making clothing, in 1930, the discovery of bone needles was found in the ruins of the Upper Cave Man at Longgu Mountain in Zhoukoudian, Fangshan District, suburb of Beijing, fully indicating that animal skins and other materials from the late Palaeolithic age in China have been used to sew clothing, and the thread sewing the clothing may be a string split with animal ligaments [16]. According to the unearthed clothing tools such as bone needle and bone cone, Chinese scholars reconstructed primitive clothing (figure 3 ). It can be seen that this kind of clothing

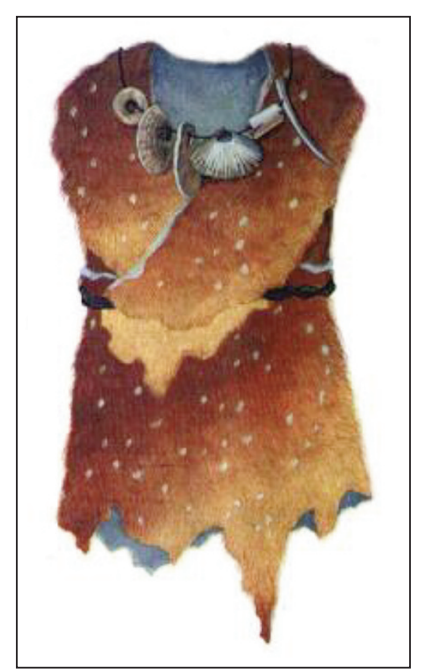

Fig. 3. Recovery drawing of original shaped clothing 
mainly covers the part of the body, and the rope belt made of leather is used to fix the clothes on the body, which should be the prototype of the original clothing. A large number of bone needles have also been found in the remains of the late Palaeolithic era worldwide. For example, there are bone needle fossils or bone needle discovery in the remains of Neanderthals, Kramaon people in Europe [17], or the Aboriginal in Australia and native Indian tribe in American. Therefore, in the late Palaeolithic period, the emergence of bone needles all over the world fully indicates that primitive people in this period were able to sew real clothes.

\section{CONCLUSION}

For the study of the origin of clothing, there are some dilemmas in the research routes of philology, archaeology and anthropology. On the whole, the research route of philology is obviously the ancient people's research on primitive people's dressing motives, and there are some deficiencies in historical explanations of Whig. Due to the lack of cultural relics, the research route of archaeology cannot reasonably explain the time and material of clothing origin. The anthropological research route is also of a congenital defect that looks at the overall problem from a one perspective. However, the combination of ancient Chinese character etymology and philosophy may be an effective way to solve the problem of clothing origin. From the perspective of ancient Chinese character etymology, the ancient Chinese characters related to clothing can fully prove that garments originated from carrying tools, and it is an effective means of primitive human survival. From a philosophical point of view, on the one hand, the emergence of clothing should be much earlier than the clothing consciousness, so the aesthetic consciousness can only be the motivation to promote the development of clothing rather than the root of the origin of clothing. On the other hand, clothing is a powerful tool, which greatly improves the survival rate of human beings. Based on the cross-analysis of ancient Chinese characters and philosophy, clothing originated from the need of carrying tools, whose initial form should be the leather belt. With the evolution and development of human beings, various shaped garments are finally produced in different regions.

\section{ACKNOWLEDGEMENTS}

Authors thank to Chinese Ministry of Education for giving financial support for this study.

\section{REFERENCES}

[1] Bernard, C., History of Science, Science Press, Beijing, 1959

[2] Tao, Y., Yu, W.D., Study on origin of costume based on functions of carrying tools, In: Journal of Silk, 2015, 5, 71-75

[3] Du, W.Q., Yan, Y.X., Wang, Y., Liu, H.G., Yin, X.Y., He, J., Interpreting configuration of ancient Chinese characters - a new method to understand terms in Huangdi Neijing, In: Journal of Beijing University of Traditional Chinese Medicine, 2017, 8, 626-629

[4] Li, Z.H., The History of Beauty, Cultural Relics Publishing House, Beijing, 1981

[5] Zhou, Z., translated by Zhang, G.G., Full Translation of Zhuangzi, Guizhou People's Publishing House, Guiyang, 1991

[6] Lu, Y.R., Lu, Y.M., The Complete Explain of the Book of Rites and Filial Piety, Guizhou People's Publishing House, Guiyang, 1998

[7] Zhang, Y., Guo, Z.T., Deng, C.L., Zhamg, S.Q., Wu, H.B., Zhang, C.X., Ge, J.Y., Zhao, D.A., Li, Q., Song, Y., Zhu, R.X., The first place in Zhou kou dian with fire magnetic susceptibility and chroma evidence, In: Chinese Science Bulletin, 2014, 8, 679-686

[8] Chen, C.D., An analysis of the generation of ancient Chinese false books, In: The Library Journal of Henan, 1984, 4, 57-60

[9] Jia, N.P., Zhoukoudian ruins, In: Cultural Relics, 1978, 11, 89-91

[10] A, Z.M., C14 dating and its problems of the late Paleolithic in China, In: Acta Anthropologica Sinica, 1983, 4, 342-351

[11] Qiao, H., Zhang, X.G., My opinion of the origin of clothing, In: Journal of Silk, 2003, 10, 51-53

[12] Gao, X., Collaboration and integration among paleoanthropology, archaeology and genetics, In: Acta Anthropologica Sinica, 2017, 1, 131-140

[13] Wu, X.Z., A brief introduction of human evolution, In: Chinese Journal of Nature, 2010, 42, 63-66

[14] Grosse, E., The Origin of Art, Commercial Press, Beijing, 1984

[15] Ye, L.C., Costume Aesthetics, China Textile Press, Beijing, 2007

[16] Huang, N.F., Chen, J.J., History of Chinese Clothing, Shanghai People's Publishing Press, Shanghai, 2014

[17] Liu, L.J., A brief introduction to Australian aboriginal culture, In: Journal of Shaotou University (Humanities BImonthly), 1997, 6, 51-58 
Authors:

QIANG LI ${ }^{1}$, ANDING LIU², BIN LI ${ }^{2}$, YIXIAO LI ${ }^{3}$, XIANMING XU², HUI TAO ${ }^{2}$

${ }^{1}$ Wuhan Textile University, Editorial Office of Fashion Guide, Minzu Avenue in Hongshan District, 430073, Wuhan, China e-mail: liqiang800121@foxmail.com

${ }^{2}$ Wuhan Textile University, School of Fashion,

Minzu Avenue in Hongshan District, 430073, Wuhan, China

e-mail: libin790121@qq.com

${ }^{3}$ Institute of Textiles \& Clothing, The Hong Kong Polytechnic University, Hong King, China e-mail: 953592363@qq.com

\section{Corresponding authors:}

ANDING LIU

e-mail: 364944277@qq.com

XIANMIN XU

e-mail: xuxianmin99@gmail.com

HUI TAO

e-mail: 932678733@qq.com 